\title{
Rainwater infiltration in the urban areas
}

\author{
G. Markovič, M. Zeleňáková, D Káposztásová \& G. Hudáková \\ Institute of Building and Environmental Engineering and \\ Institute of Architectural Engineering, \\ Technical University of Košice, Slovakia
}

\begin{abstract}
A serious problem in recent years of waterworks praxis has appeared to be the one with growing necessity for surface water detention. Continuous growth of natural terrain coverage for building construction, industry, free time activities and transport reasons leads to a widening of the area of build surface and lack of natural terrain with a capability of natural rainfall water infiltration. This causes serious damage to the natural water cycle. In cases where rainfall water falls on natural terrain, most water soaks in the soil and becomes part of the subsoil water. Only about $20 \%$ of rainfall water comes to rivers or is carried to stormwater drainage. As a consequence of the continuous growth of building construction and urban development, the natural terrain is replaced by compact soil; for example, the roofs of industrial, residential, commercial or other buildings, road networks, car parks etc. When the rainfall water reaches these surfaces almost $80 \%$ of this water flows to the waste-water disposal system or rivers and only $20 \%$ soaks into the soil. This leads to ecological damage as floods, torrential rain, and the decline of subsoil water level, local soil dehydration and endangering of sensitive ecosystems. It is necessary to build and develop not only urban constructions but also the artificial regulation of water circulation in nature, which contribute to the maintenance of ecological stability of the chosen location.
\end{abstract}

Keywords: drainage, infiltration, rainwater, runoff, shaft.

\section{Introduction}

Urban rainwater drainage must be controlled in order to avoid flooding and to keep safe human health and property. Traditionally, urban storm drainage 
systems have been designed for hydraulic efficiency to transport rainwater from the urban environment as quickly as possible [1].

Prior to development, rainwater is a small component of the annual water balance. However, as development increases, the paving of pervious surfaces with new roads, shopping centers, driveways and rooftops all adds up to mean less water soaks into the ground and more water runs off. Overall, urban drainage presents a classic set of modern environmental challenges: the need for cost-effective and socially acceptable technical improvements in existing systems, the need for assessment of the impact of those systems, and the need to search for sustainable solutions [2].

The movement towards making better use of natural drainage mechanism has been given different names in different countries. For example in US 'best management practices' or BMPs, in Australia 'water sensitive urban design' and in the UK 'Sustainable Urban Drainage Systems' or SUDS. These techniques including soakaways, infiltration trenches, swales...etc concentrate on stormwater. The possible solution appears also in the separate drainage system. The stormwater is not mixed with the wastewater and can be discharged to the watercourse at the convenient point. However, the obvious disadvantage might be cost.

The majority of drainage systems in Slovakia are combined; like in the UK, France and Germany, where about $70 \%$ of total drainage system length is combined, according to Butler and Davies [2]. Nowadays, we know that this kind of system is economically and environmentally inefficient and in many cases causes overloading of sewerage systems and treatment plants as more frequent floods prove it. It is essential that we introduce new sustainable approaches in urban drainage systems in Slovakia as well.

\section{Rainwater infiltration}

Infiltration facilities are devices designed for fluent and natural infiltration of rainwater from the roofs of buildings and paved surfaces. The basic principle and function of all types of infiltration facilities as quickly as possible to divert rainwater to infiltration zone and there it infiltrates into the surrounding soil [11]. Design and use of infiltration facilities as a sustainable method of rainwater runoff disposal become an integral part of the drainage management and projects of sewerage system of buildings or other paved surfaces.

Disposal, respectively safe drainage of rainwater is a problem of almost every new building in an urban area and in area with undersized sewage systems. Waste-water disposal systems, sewage treatment plants and recipients of water flows are overloaded and the risk of floods grows. This represents another reason for waterworks companies to have the possibility of forbidding the disposal of rainfall water from surface detention into the waste-water disposal system already during the creation and fulfillment of the development plan. This leads to the necessity of using rainwater infiltration systems or capturing rainwater for further reuse. 
For this reason, it is appropriate to design infiltration systems, which not only solve a technical problem that partially relieve a sewer network, but also contribute to the ecological stability of ecosystems, and also reduce expanse for disposal of surface water from rainfall runoff into a waste-water disposal system.

\subsection{Positive aspects of rainfall infiltration systems}

\subsubsection{Ecological aspect}

A cycle of water circulation in nature consists of the following phases: precipitation, infiltration, runoff, evaporation.

In the case that rainwater falls on natural terrain, most water infiltrates to the soil and becomes a part of subsoil water. Only about $20 \%$ of rainfall water comes to rivers or is carried to rainwater drainage.

The problems associated with urbanization originate in the changes in landscape, the increased volume of runoff, and the quickened manner in which it moves. The changes in the landscape occurred during the transition from rural and open space to urbanized land use [4].

Urbanization causes a shift from sub-surface pathways dominating stream flow generating processes to overland flow as vegetation is removed and soils become compacted or covered with impervious paving or roofs. Rainwater runoff is largely caused by rain falling on asphalt or roofs and storms $[4,9]$. Impervious surfaces are the results of new developments as well as further developments within existing areas and lead to increased rainwater runoff. It is not only the volume of runoff but also the speed of runoff that increases [5].

In heavily urban areas, the natural terrain is replaced by paved surfaces. When rainwater reaches these surfaces, almost $80 \%$ of this water flows to the wastewater disposal system or rivers and only $20 \%$ infiltrates to the soil. This leads to the above mentioned ecological damage.

\subsubsection{Technical aspect}

The drainage of excess volumes of rainwater from large areas of roofs and paved areas is also a technical problem. Designing infiltration facilities reduces initial flow of the first volume of influent rainwater and reduces overloading sewer systems especially in the initial phase of short torrential rains and reduces the risk of flood.

The growth of urban areas increases velocity and amount of rainwater runoff. As a result of such growth, existing rain drainage systems are sometimes exceeded. This is especially the case of larger cities with combined sewer systems. Heavy rainfall can cause temporary overloading the system [5].

\subsubsection{Economic aspect}

Rainwater infiltration system brings also economic advantages especially when prices of water rate and sewage charges grow constantly. The reason for forcing these prices up is growth of expenses for drinking water-purification and wastewater treatment. Other reasons are declining level of subsoil water and lack of drinking water resources. In years to come the situation won't change or it will be even worse. The prices will grow continuously. The implementation of 
rainwater infiltration system on private property will help the owner to reduce expenses for conducting rainwater to a waste-water disposal system.

\section{Requirements for the design of infiltration facilities}

The infiltration facility as a method of rainwater drainage must ensure the safe drainage of rainwater at the required time. With the correct design, realization and maintenance of infiltration facilities, it should be operation of this device fluent and without complications. It is therefore necessary that the designer of the infiltration facilities knows hydrogeological conditions in the area of interest. The design of infiltration facilities must take into the account protection of groundwater and infiltration capability of soil.

Percolation facilities (soakaways) are wastewater facilities. The soil in these facilities and the substances retained are parts of this wastewater facility. Objective of a sustained soil and groundwater protection has to be permanently to maintain the natural functions of the soil, above all its efficiency as filter, buffer and transformer, and to keep groundwater as far as possible unaffected by human influences as well as to preserve soil and groundwater across the whole area from pollution or other disadvantageous changes [7].

A very important design parameter of infiltration facilities is to determine the infiltration coefficient $k_{\mathrm{f}}$ in the interest area. The infiltration coefficient $k_{\mathrm{f}}$ generally represents an efficiency of infiltration facilities, respectively infiltration capability of the soil to absorb the inflow water.

Permeability of the infiltration zone is a main qualitative and quantitative requirement for rainwater infiltration. Permeability of loose rock depends primarily on the size and distribution of the particles and compactness, in soils is critical soil structure and water temperature and is given by the infiltration coefficient. Permeability of loose rock varies in general between $1.10^{-2}$ and $1.10^{-10} \mathrm{~m} / \mathrm{s}$. The $k_{\mathrm{f}}$ values apply to the process of infiltration water in the saturated zone. The range of values for the filtration coefficient for technical drainage ranges from $1.10^{-3}$ and $1.10^{-6} \mathrm{~m} / \mathrm{s}$ [10].

The $k_{\mathrm{f}}$ values greater than $1.10^{-3} \mathrm{~m} / \mathrm{s}$ cannot be reached for rainwater runoff and low depth of groundwater level the sufficient pretreatment through chemical and biological processes. If the $k_{\mathrm{f}}$ values are smaller than $1.10^{-6} \mathrm{~m} / \mathrm{s}$, the percolation facilities are loaded very long time. For this reason, anaerobic processes in the unsaturated soil, which resulting in adverse effects on retention and capacity capabilities of the soil can occur.

Therefore, the most important design parameter of the infiltration facilities is to determine the filtration coefficient $k_{\mathrm{f}}$ on-site.

\section{Experimental research of infiltration in the campus of TU Košice}

The project APVV SUSPP-0007-09 related to the management of rainwater, taking place at the Faculty of Civil Engineering in Košice, deals with the research of infiltration shaft as one of the types of infiltration facilities. 
The research of rainwater infiltration takes place in infiltration shafts that were constructed before the start of the research. Both infiltration shafts A and B are located by the PK6 building in campus of the Technical University of Kosice. Rainwater runoff from the roof of this building flows into the two infiltration shafts (figure 1).

As was already mentioned above, the most important parameter of design not only for infiltration shafts, but in general infiltration facilities, is to determine the infiltration coefficient $k_{\mathrm{f}}$ in the interest area. The filtration coefficient of surveyed infiltration shafts was through the laboratory tests set at $k_{\mathrm{f}}=1.10^{-3} \mathrm{~m} / \mathrm{s}$ [6]. Theoretical analysis of infiltration shaft efficiency respectively of the time required for infiltration of inflow rainwater from the roof of the building PK6 was processed for the studied infiltration shafts.

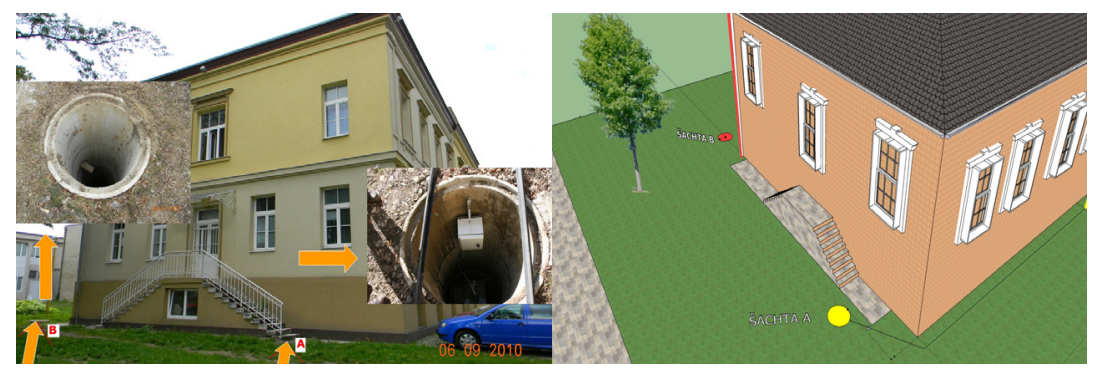

Figure 1: $\quad$ Location of infiltration shafts near building PK6

As a result of the theoretical calculation, the efficiency of infiltration shaft respectively time required for infiltration of rainwater inflow for $k_{\mathrm{f}}=1.10^{-3} \mathrm{~m} / \mathrm{s}$ in studied infiltration shaft would be ranges of minutes.

\subsection{Efficiency of infiltration facility (shaft) in real conditions}

Real values of infiltration shaft efficiency respectively of the time required for infiltration of inflow rainwater from the roof of the building PK6 in campus of the Technical University of Kosice are shown in figures 2 and 3 [6].

Figures 2 to 4 represent 2 selected rainfall events from every year of research showing the process of inflow rainwater into the infiltration shaft, calculated volume of inflow rainwater and process of water level change at the bottom of infiltration shaft A. The time for infiltration of rainwater at the bottom of the shaft basically follows the process of precipitation, respectively inflow of rainwater into the shaft.

Resulting not only from figures 2 and 3, but also from the overall measured data during the research, the total infiltration of rainwater in the infiltration shaft, take place at the time of termination of rainfall events, respectively short-time after, which represent a high infiltration rate of this shaft, given by the coefficient of infiltration of soil at the bottom of shaft. Therefore, despite the smaller surface for infiltration of infiltration shafts with comparison to other 


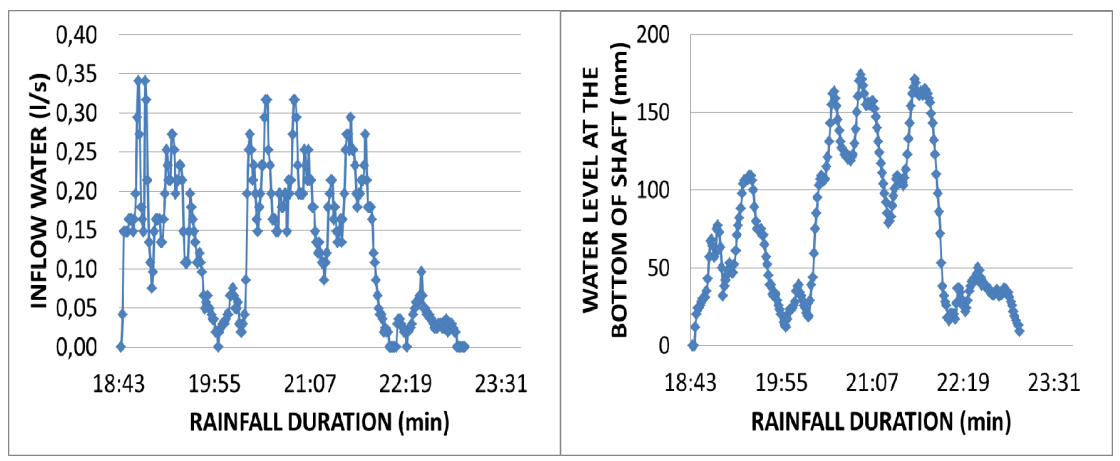

Figure 2: Volume of rainwater inflow and water level changes at the bottom of shaft during rainfall 7.10.2011 [6].

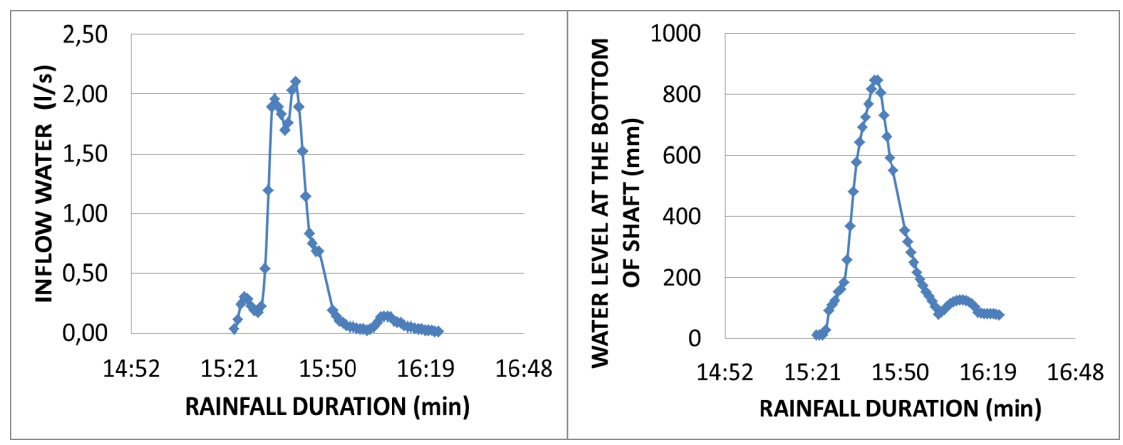

Figure 3: Volume of rainwater inflow and water level changes at the bottom of shaft during rainfall 1.9.2013.

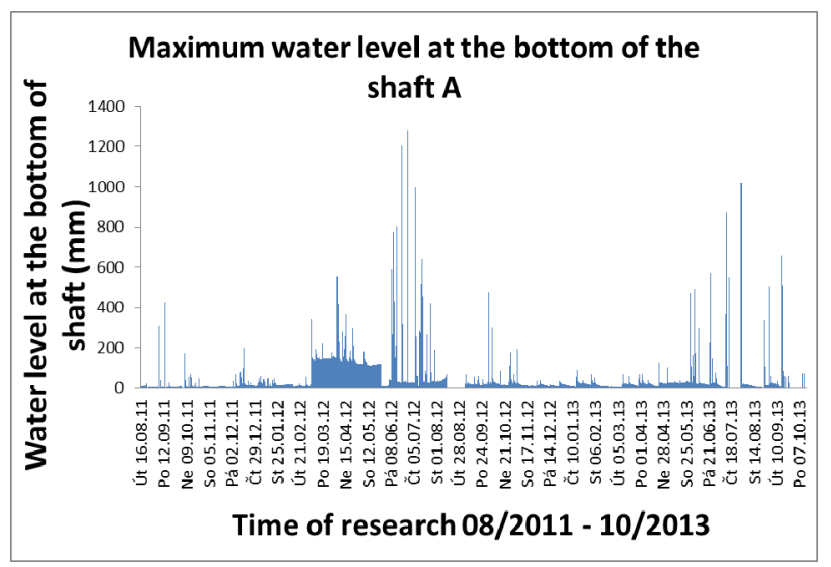

Figure 4: Values of maximum water level at the bottom of the shaft A from August 2011 to October 2013 [6]. 


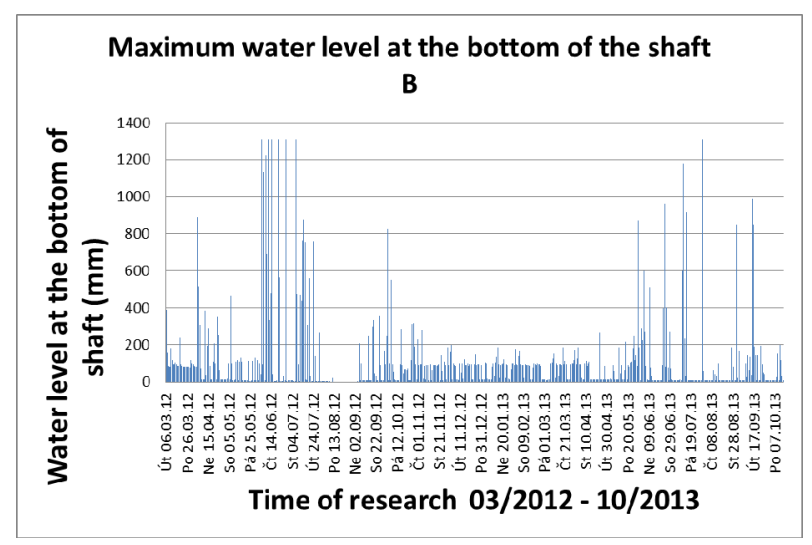

Figure 5: Values of maximum water level at the bottom of the shaft B from March 2012 to October 2013 [6].

types of infiltration facilities, the infiltration coefficient of surveyed infiltration shafts $k_{\mathrm{f}}=1.10^{-3} \mathrm{~m} / \mathrm{s}$ ensures safe disposal of surface runoff. The maximum water level at the infiltration shafts are shown in figures 4 and 5 [6].

\section{Conclusion}

Infiltration of rainwater, taking into account the suitability of local conditions appears to be the most suitable environmentally solution of rainwater drainage. The connection of conventional method of draining rainwater through sewer systems and infiltration of rainwater appears to be the most suitable drainage concept for sustainable cities.

As was mentioned above, suitability of choice of type of infiltration facility is dependent on local conditions. There are several types of infiltration facilities. In general, infiltration facilities may be divided into surface and underground devices, so that in the case of limited available surface in urban areas it is necessary to design underground infiltration facilities. Infiltration shaft is very suitable solution of rainwater drainage. Of course, it is necessary to take into account the principles of design of these facilities, for example separation distance from buildings, groundwater level, infiltration coefficient etc.

But it is always necessary to consider from the view of local conditions about suitability of rainwater infiltration solutions. Therefore, in each case, it is to be considered carefully, which drainage concept in combination with the percolation of precipitation is ecologically sensible, technically possible and economically justifiable [7].

\section{Acknowledgements}

The authors are grateful to the VEGA 1/0450/12 Energy balance research on rainwater management in the cities of the future and to the Slovak Research and Development Agency under the contract No. SUSPP-0007-09. 


\section{References}

[1] Semadeni-Davies, A. and Bengtsson L. (2000), Theoretical Background, Chapter 1 in: Vol II. Urban Drainage in Cold Climate, IHP-V, Technical Documents in Hydrology, No. 40, UNESCO, Paris

[2] Butler, D. and Davies, J. W. (2011), Urban Drainage, 3rd Edition, Spon Press an imprint of Taylor \& Francis, ISBN 978-0-415-45526-8

[3] Technické podklady firmy Wavin, WAVIN AZURA - WAVIN Q-BIC, 2006.

[4] Minnesota Stormwater Manual (2008), Version 2, Minnesota Pollution Control Agency, online: http://www.pca.state.mn.us/

[5] Stahre, P. (2006), Sustainability in Urban Storm Drainage, Planning and examples, Svenskt Vatten, ISBN 91-85159-20-4

[6] Markovič G. (2012), Trvalo udržatel'né nakladanie so zrážkovými vodami z povrchového odtoku pri odkanalizovaní budov, Thesis, Košice.

[7] Standard DWA-A 138E, (2005), Planning, Construction and Operation of Facilities for the Percolation of Precipitation Water.

[8] Vranayová, Z. (2003), Posúdenie trvalej udržatelnosti systémov využitia vôd z povrchového odtoku, Habilitačná práca, Košice.

[9] Karelová, Z. (2010), Stormwater Management in Compliance With Sustainable Design of Buildings and Environmental Conception. Doctoral thesis - theory. Košice: Technical University of Košice.

[10] Vrána, J. (2010), Dimenzování vsakovacích zařízení v ČR. In Sanhyga, s. 29-36, Piešt’any.

[11] Vranayová, Z. (2004),Využitie zrážkových vôd z povrchového odtoku - 1. čast' Legislatíva a možnosti akumulácie. In: Technické zariadenia budov. Roč. 12, č. 6, s. 40-43.

[12] Vranayová, Z. (2005), Využitie zrážkových vôd z povrchového odtoku - 2. čast': Uživatel'ské režimy a účinnost' systémov. In: Technické zariadenia budov. Roč. 13, č. 1, s. 29-32. 